\begin{tabular}{l|l}
\hline Notaice & e-ISSN: 2655-9404 \\
Vol. 2 No. 2, Juni 2019 & DOI: 10.20473/ntr.v2i2.13097 \\
\hline
\end{tabular}

Article history: Submitted 13 May 2019; Accepted 28 May 2019; Available online 1 June 2019.

\title{
Copyright Protection of Video Game for Game Developer in Indonesia
}

\author{
Juanda Maria Angelia Yolesa, Annisa Ayu Mulia and Camellia Anand \\ mariajuanda94@gmail.com \\ Universitas Airlangga
}

\begin{abstract}
This study aimed to firstly, analyze the frequent infringements related to copyright of video games, as well as the legal protection for game developers who create video games. Secondly, to determine the factors that impede the copyright protection of video games in Indonesia. This research employs empirical approach or sociolegal, with library research and field studies to collect data. In the literature, the author uses the legal resources to support the analysis. The study was based primarily on Law no. 28 of 2014 regarding Copyright. In the field study, the author interviewed several game developers in Indonesia, as well as the practitioner from Directorate General Intellectual Property Right Jakarta and academician from Faculty of Law Universitas Gadjah Mada. Analysis of the research was conducted using qualitative data analysis, with the results compiled by descriptiveanalysis to achieve the research objectives. Results of this study indicates that the laws and regulations of Indonesia has virtually provided legal protection for game developers as the creator of the video game, but there are still uncertainties in settings, such as obscurity any part of the video game that is protected by the copyright laws of Indonesia, considering that the video game consists of several constituent.
\end{abstract}

Keywords: Legal Protection; Copyright; Video Game.

\section{Introduction}

In this modern era, the world has been through rapid growth and advanced development in the field of science and technology. This field has attracted the most attention because of a profound effect on people's lives and continues to grow in line with the challenges of the times. ${ }^{1}$

Developments in technology have brought enormous benefits to almost all people, ${ }^{2}$ for example a computer helps people to resolve their jobs better and more efficiently, compared with a typewriter. The development of human creativity encourages new findings in technology which can be used as means of

\footnotetext{
1 Aprinus Salam, Negara Dan Perubahan Sosial, Sastra (Pusat Studi Kebudayaan UGM 2010).[399].

2 Science for All Americans Online, 'Chapter 3: Nature of Technology, Issues in Technology’ (Science for All Americans Online, 2019) <http://www.project2061.org/publications/sfaa/online/chap3.htm\#top.> accessed 12 April 2019.
} 
improving the welfare of mankind. ${ }^{3}$ One of the products of the human being is video game. The creation of video game has benefits as means of entertainment and education. ${ }^{4}$

Basically, video game is a game using electronic media. Video game is a form of multimedia entertainment that is made as attractive as possible so that players obtain pleasure and satisfaction through playing. ${ }^{5}$ Playing games are one means of learning. ${ }^{6}$ Educational games have been created with the specific purpose as an educational tool, for example to learn about colors, recognize letters and numbers, math, and also to learn a foreign language. Video games are so influential for the human mind, which are absorbed through two senses, sense of sight and sense of hearing. ${ }^{7}$ Another research has proven feature of playing video games includes the ability to improve fine motor skills. Games can train motor skills, and train us to link these skills with a quick visual signal and improve hand and eye coordination. ${ }^{8}$ Surgeons have proven to work better when they spend at least a few hours a week playing video games. At The University of Texas Medical Branch test, teen gamers could outrank practitioners in surgical robotic surgery simulator training at the school. ${ }^{9}$ In line with the growing popularity of video games, there are more varieties of games that have appeared. In planning and shaping a game, the game developers need hard work, creativity, and expensive costs. ${ }^{10}$ It is very unfair if the game they laboriously create are hijacked by irresponsible developers trough piracy.

3 Samaun Samadikun, Sang Petani Silikon Indonesia (LIPI Press 2007).[28], quoted from Kompas, 'Indonesia Abad XXI, Di Tengah Perubahan Global' Kompas (Jakarta, 2000).[293-304].

4 Rudi Susilana dan Cepi Riyana, Media Pembelajaran: Hakikat, Pengembangan, Pemanfaatan, Penilaian (CV Wacana Prima 2009).[163].

5 Michele D. Scott, Scott of Multimedia Law 3rd Edition Vol. 1 (Wolter Kluwers Law and Business 2008).[24].

6 Samuel Henri, Cerdas Dengan Game (Gramedia Pustaka Utama 2010).[68].

7 Pepen Supende and Nurhidayat, Fun Game 50 Permainan Menyenangkan Indoor Dan Outdoor (Penebar Swadaya 2008).[32].

8 James Butch Rosser, Playin'To Win: A Surgeon, Scientist and Parent Examines the Upside of Video Games (Morgan James Publishing 2009).[119].

9 The University of Texas Medical Branch (UTMB), 'UTMB's Dr. Kilic on the Robotic Simulator Training Study’ (The University of Texas Medical Branch (UTMB), 2019) <https://www. youtube.com/watch?v=9hhnG-uwq4o $>$ accessed 9 April 2019.

${ }^{10}$ Rusel DeMaria, Reset: Changing the Way We Look at Video Games (PTY Ltd 2008). [61]. 
Piracy is an issue that is largely affecting the game developing industry. ${ }^{11}$ Piracy is a quick way to get games in easily with cheap price. ${ }^{12}$ However, piracy is also a quick way to render the maker or developer of video games poor, causing them to lose their livelihood.

When viewed closely, game project of a game developer covers some rights. There are copyright of the characters, music, story, code and art; trade secret of customer mailing lists, pricing information, publishing contacts, developer contacts and middleware contacts; trademark from the company name, logo, game title, game subtitle and identifiable catch phrases associated with game/company; and patent such as software, hardware technical solution, game design elements and networking or database design. ${ }^{13}$ Therefore it can be said that a video game is a collection of Intellectual Property.

Copyright issues will touch on various aspects such as aspects of technology, industrial, social, cultural and various other aspects. The most important aspect in relation to the protection of intellectual property is the legal aspect. ${ }^{14}$ Law is expected to overcome the various problems that arise are related to copyright. Laws should be able to provide protection for intellectual work, so as to develop the creativity of society which ultimately led to the success of the objectives of copyright protection.

The development of video game which pampers the players with sophisticated technologies is an interesting phenomenon to observe. The development of increasingly advanced technology requires the legal protection of video game copyright to avoid any violation of the law of the copyrighted works of video games. The copyright protection of video game is needed to ensure the security of rights of the creator of the game so that the creators (developers) can be more motivated

\footnotetext{
${ }^{11}$ Luke Graham, 'Can Video Game Piracy Be Stoped in Two Years?' (CNBNC.com, 2019) $<$ http://www.cnbc.com/2016/01/14/can-video-game-piracy-be-stopped-in-two-years.html $>$ accessed 14 April 2019.

${ }^{12}$ Samuel Henri (n 6).Op.Cit. [12].

${ }^{13}$ David Greenspan, Video Game and IP: Global Perpective (WIPO Magazine 2014).[9].

${ }^{14}$ Badan Pengkajian dan Penerapan Teknologi Hak Kekayaan Inteletual, 'Pengakuan Hak Kekayaan Intelektual Di Indonesia' (Badan Pengkajian dan Penerapan Teknologi Hak Kekayaan Inteletual, 2011) <http://hki.bppt.go.id/index.php?option=com_content\&view=article\&id=15\&Itemid=19> accessed 13 April 2019 ..
} 
to produce more exciting, creative and qualified video games. Unfortunately, currently Indonesia does not have any legislation that specifically regulates the protection of video games. As for the the regulation of video game contained in Article 40 paragraph (1) letter r Law number 28 of 2014 on Copyright, which categorized "Permainan Video" as one of the creation protected by Copyright Law. This provision cannot provide sufficient legal protection to works of video games because there are no details about the scope and the procedure of the protection, even there is no definition of video game (in bahasa: permainan video) referred by the law. The law only stated that the video game is protected, no further elucidation in the term video game itself. The author also wants to know the implementation of video games' protection after the enactment of the new law of Copyright number 28 of 2014.

Based on the description above, the author is interested to conduct a further analysis on these problems in the form of legal research with the title, "Copyrights Protection of Video Games for Game Developer in Indonesia”.

\section{Research Method}

The research used by the author is an empirical / sociolegal research, which this research focused on the problem with the fact that occurred in field, then connected it with the legislation in force, as well as the principles of law. ${ }^{15}$ The author use the library research, is a kind of research that is done by collecting, studying and analyzing data from a variety of materials of written literature to be able to get answers to the problem to be researched. ${ }^{16}$ On research literature will be available secondary data where such data had been available before, so the author just needs to collect, process and analyze of some legal materials. ${ }^{17}$ The primary legal materials are materials that have the binding force of law and are closely

\footnotetext{
15 Soerjono Soekanto, Pengantar Penelitian Hukum (UI-Press 1984).[47].

16 Soerjono Soekanto, Penelitian Hukum Normatif (Raja Grafindo Persada 2006).).[13].

17 Soerjono Soekanto (n 15).Loc.Cit.[12].
} 
related to the issues to be studied..$^{18}$ Primary legal materials that become the source in the writing of this legal reseach are listed below, but not limited to (1) Law Number 28 of 2014 on Copyrights; (2) Law Number 19 of 2002 on Copyrights; (3) Agreement on Trade Related Aspects of Intellectual Property Rights (TRIPs); (4) Indonesian Civil Code; (5) Berne Convention for the Protection of Literary and Artistic Works. And secondary legal material, is a legal substance that is closely related to the primary legal materials which can provide clues and explanations above primary legal material. ${ }^{19}$ The secondary legal material obtained from books, papers and research results, as well as articles related to problems researched. Last, the author use tertiary legal material, that is materials give instructions and explanations of the primary and secondary legal materials, such as dictionaries, that used to help in finding specific meanings or devinitions of terminologies failing the previous authorities. ${ }^{20}$

Not only use that method, this research is conducted towards the respondents as well as the resource persons in order to obtain the necessary datas. Respondents are those who experienced the events which is being researched. Respondents in this research are several video game developers in Indonesia, he is Roki Soeharyo (COO of Touchten), Kris Antoni (CEO Toge Production), Eka Pramuditha Muharram (CEO Mojiken Studio), Maulidan Bagus Afridian Rasyid (Founder of Maulidan Games), etc.

Resource persons are those who have expertise in the law of Intellectual Property rights, consists of both academic as well as practitioner. The research person from this research are Wiwin Setiowati K. From Law and Litigation Department of Directorate General of Intellectual Property Rights Jakarta, and Tomi Suryo Utomo, lecturer in the Faculty of Law of the Universitas Gadjah Mada.

Data collecting tool used in this research is the interview guideline contains a list of questions, but not limited to the preliminary list. It means that the questions

18 and Scragg Greville, Davidson, Legal Research and Writing in New Zealand (3rd edn, Lexis Nexis 2007).. [56].

${ }_{19}$ Peter Mahmud Marzuki, Penelitian Hukum (Kencana Prenadamedia Group 2005).[155].

${ }^{20}$ Soerjono Soekanto (n 16).Op.Cit., [52]. 
only contain the outline and may open up possibilities for other questions outside the list of questions as long as it is not in contradiction and still have a correlation to the problems.

This study used qualitative method of data analysis, which is represented in words. The qualitative method conducted by producing a completion of the data obtained based on quality and its truth has a relevance to the research that is discussed. Therefore, this analysis involves a constant interplay between collection of the data and analysis that produces growth of understanding. ${ }^{21}$ This research uses qualitative method of data analysis because the information gathered is a nonnumerical data, therefore, it shall be analyzed by using the interpretative method. ${ }^{22}$

\section{The Infringements Which are Often Encountered Regarding Copyright Protection of Video Games in Indonesia}

Cracking the video game using a software, and then extracted and take the desired parts. It may also be done by conducting a reverse engineering using the source code of a game that has been extracted. It is very easy to do for a game on the Android platform and flash games because the. Apk file on Android and .swf in flash can be installed and unpacked easily.

Manually creating the parts in the game, this is similar as imitating the parts of the game. This method is conducted by using the observation method. So the offender by referring to a video game, make the same video game manually. Same character, music, storyline created manually.

Distributing the games without using a license of distribution of flash games on the portal (website). There are three types of license of distribution which are exclusive distribution, Primary distribution and non-exclusive distribution. i) Exclusive distribution is giving distribution rights of a product to one distributor without time limitation. It is an agreement which requires the Creator's hand over

${ }^{21}$ Nicholas Walliman, Your Undergraduate Dissertation (Sage Publication 2004).[163].

${ }^{22}$ Suharsini Arikunto, Prosedur Penelitian: Suatu Pendekatan Praktek (Rineka Cipta 1996). [120]. 
his work through the full payment by the buyer so that the economic rights on the work shift entirely to the buyer (sold flat). Game developers may not sell the game to another party. In this model, game developers can still use the source code, unless the agreement source code also includes as subject to the sale. ii) Primary distribution is granting distribution rights to one distributor for an agreed period. After the agreed time expires, the game developer can sell the game to another party at a cheaper price. iii) Non-exclusive distribution is granting distribution rights to another party after the period of primary distribution expired. Game developers can sell to several parties. If there are people who distribute the games without a license, it will be considered as copyright infringement of the game.

Based on the interviews conducted with respondents, the author obtained a lof of information related to the infringement of copyright, due to advances in technology. Based on the results of the study, 3 out of 4 game developer respondents in this study found that the work of video game experience copyright infringement. The infringement experienced by the respondent of this legal research can be seen in below table:

Table 1. copyrights infringements which happened in the field.

\begin{tabular}{cccc}
\hline Game Developer & Name of Game & Platform & Infringement experienced \\
\hline Ramen Chain & Mobile iOS & $\begin{array}{c}\text { The game was republished with } \\
\text { different tittle and adding in-app- } \\
\text { purchase system }\end{array}$ \\
\cline { 2 - 5 } Touchten & Infinite Sky & Mobile iOS & $\begin{array}{c}\text { The game was republished with } \\
\text { different tittle and adding in-app- } \\
\text { purchase system }\end{array}$ \\
\cline { 2 - 5 } & Sushi Chain Lite & Mobile iOS & $\begin{array}{c}\text { The video game was modified with } \\
\text { not-so different characters, graphics } \\
\text { and its types of sushi }\end{array}$ \\
Mojiken & Vamps Revenge & Web Portal (Flash) & $\begin{array}{c}\text { The game was republished in the } \\
\text { application and claimed under the } \\
\text { infringer's own copyright and sold } \\
\text { in premium price }\end{array}$ \\
\end{tabular}




\begin{tabular}{ccc} 
Toge Productions $\quad$ Infectonator $2 \quad$ Web Portal (Flash) & $\begin{array}{c}\text { The video game was republished } \\
\text { in application market under the } \\
\text { infringer's copyright and add app- } \\
\text { in-purchase }\end{array}$ \\
Eka Pramudhita $\quad$ Chase Burger $\quad \begin{array}{c}\text { Mobile Symbian, } \\
\text { Web Portal (Flash) }\end{array}$ & $\begin{array}{c}\text { The video game was republished } \\
\text { in application market under the } \\
\text { infringer's copyright }\end{array}$ \\
\hline
\end{tabular}

\section{Copyright Protection of Video Game for Game Developers in Indonesia}

On the internet, piracy has become an even larger mass phenomenon due to the availability of perfect digital copies. Developments in technology seem to take away the grounds for copyrights. The relationship between Law and privacy is a very complex issue. For such reason, the video game developers prefer to conduct preventive efforts with the use of Technology. According to the respondents, it is more secured if compared to registering the copyright. Preventive protection is done using the data security system/digital information. These systems called the electronic rights management systems (ERMS), or the digital rights management systems (DRM). Digital data security is done to protect digital information of a work in order to secure the data contained therein, so that it is not hijacked by the third party. One of them is by securing data.

DRM is term that refers to access control technologies used by creators or copyright holders to limit usage of digital media or devices, usually from the pirates of intellectual property rights. The copyright holder is usually the creator of music, movies, software, books or video game. DRM is used to oversee how the document, the entire software program used. The term can also be interpreted as a restriction on a specific part of a work or digital means. DRM was developed and implemented in an effort to prevent copyright infringement and the financial loss suffered by the video game industry. Here are some of the security technology related to DRM which is usualy used by game developers to secure their video game, including:

I. Cryptography is used to keep the contents of data or messages in order to remain safe, can not or are difficult to access by other people who are not eligible. 
Cryptography secure data by scrambling the data, change the composition of his character and replace characters with other characters (substitution). Basically the main concepts of the Cryptography are:

a) Encryption: A process in which the data or information to be sent, converted first into a form that is almost unrecognizable from previous data by using a certain algorithm, so that the contents of the data is not easily known by a third party. Usually done at the sender. Encryption is how the process of encoding a message into the contents can not be understood by unauthorized people. Instead description is a process to restore encrypted messages in a condition so that it can be read again what the real message.

b) Decryption: The opposite of encryption. Decryption is a process by which the data is encrypted before the data is converted back to the beginning, usually performed at the receiver. To find the information contained therein. This can be referred to as reverse engineering.

II. Steganography is the process of storing secret message in the form of a text in another form that is not easily known by others. The content and meaning of the message can only be decoded by the manufacturer and the person entitled to receive the message. If the cryptographic message is encoded / encrypted such that it is not known what the contents of the message, steganography in focus is that the existence of secret messages disguised itself.

III. Watermarking, the process of concealment of data / messages into other data with the intent of certain safeguards. One of the goals of watermarking is often used as a label of copyright in the digital data or as authentic evidence of ownership of a particular digital document.

Based on observations made by the author, either Touchten, Toge Production, Mojiken Maulidan, Games and almost all developers apply the most simple digital watermark which put the logos of game developers in the game they made. As well as put the logos trough hidden image in video games such as adding a logo on the building in the game. But according to Kris Antoni, the video games hijackers do not hesitate to take a game with logo of the creator on it, so the pirated game still 
has the developer identity who creates it.

According to Jonathan M. Gunawan, there is the simplest way to protect the source code of a video game using the techniques of Obfuscation. Obfuscated code is disguising technique in order not easily be read by other people. Programmers may deliberately obfuscate code to conceal its purpose (security through obscurity) or its logic to prevent tampering, deter reverse engineering, or as a puzzle or recreational challenge for someone reading the source code.

The working principle of obfuscation is not the same as encryption. Encryption hides the data with keys and change the data becomes meaningless for anyone, including the engine. This differs from the obfuscation that converts data becomes meaningful to the user (human) but can be read by a machine.

In Copyright Law also mentioned about Registration of Copyright to General List of Creation. This often makes the mistake that by registering the creation as a preventive measure to protect copyrights. In essence, copyright registration does not affect the protection of copyright on a work, because copyright is born on automatically when a creation embodied in tangible form. The function of the copyright registration is simply to facilitate the proof if there is a dispute. Registration of copyrights will be ended by granting the copyright certificate as a means of proof if any copyright Disputes later. The certificate of registration can be easily known by the registration number, the creator, the copyright holder, the type of creation, the title of creation, and the period of protection.

Based on the interview with Wiwin Setiowati K., copyright registration of video game can be done by submitting an application which writing in Indonesian by the Creator, the Copyright Holder, related rights owner, or his proxy to the Minister. The Request made shall include i) includes a sample of the work, for video games as much as 2 CDs; ii) attach a statement of ownership of Works and Related Rights; and iii) to pay the costs.

Based on the research conducted by the author, none of the respondents registered the copyright in a video games that they made. The reasons are because copyright registration is not the focus of the video game developer, they are confused 
about copyright registration and they distrust the copyright laws in Indonesia, they questioned whether if they register the copyright then their games are completely protected. Video game developers also felt that the effort to register the copyright is something which is spends time, energy and money for ineffective enforcement.

Based on research conducted in the field, there has not been any game developer in Indonesia that use litigation to handle the copyright issues. Developer Touchten and Toge Productions use consultation and obtain legal advice from a lawyer who said that litigation costs are very large and the process is more expensive than the value that is in the Touchten's game that being infringed. The result of the consultation is to immediately send a warning letter to the people who infringed the copyright. Then Touchten also report it to the AppStore and iTunes. To strengthen the evidence in the AppStore and iTunes, Touchten collected evidence to prove that the game was originally theirs. According Roki Soeharyo, if there is a copyright infringement report and provide clear evidence, iTunes and Appstore and will take down the game because they are very appreciative towards the owner of copyright, by upholding the copyright. From the research of the author and from the explanations above, legal protection of video game for game developer in practice can be concluded with the table:

Table 3. game developers' efforts to protect their copyright.

\begin{tabular}{ccc}
\hline Game Developer & Name of Game & Efforts Conducted to Protect the Copyright \\
\hline Ramen Chain & $\begin{array}{r}\text { Digital Right Management, Consultation, } \\
\text { Warning Letter and sent report to 3rd party to } \\
\text { take down the game }\end{array}$ \\
Touchten & Infinite Sky & $\begin{array}{c}\text { Digital Right Management, Consultation, } \\
\text { Warning Letter }\end{array}$ \\
Sushi Chain Lite & $\begin{array}{c}\text { Digital Right Management, Consultation, } \\
\text { Warning Letter }\end{array}$ \\
Mojiken & Vamps Revenge & Digital Right Management, Warning Letter
\end{tabular}


Toge Productions
Infectonator 2
Digital Right Management, Consultation, Warning letter, report to the 3rd party take down the game
Eka Pramudhita
Chase Burger
Digital Right Management, Warning Letter, report to the 3rd party to take down the game

\section{Factors that Impede the Protection of Video Game in Indonesia}

The handling of copyright infringement issues are generally sufficient enough. Nevertheless there are still some things that impede the implementation of law enforcement, especially to copyright protection of video games. Applications law approach confirmed by Soerjono Soekanto states that the main problem of law enforcement is actually located on the factors that affect the law enforcement itself. These factors have neutral meaning, so the impact of negative or positive lies in the content of those factors.

From the interviews that have been conducted to the respondents and resource persons also from observation in the field, the author divided it into four different factors. The factors that impede or that make the process of copyright law enforcement in video game less effective, are:

Table 4. Factors that impede the copyright protection from game developers' perspective.

\begin{tabular}{|c|c|c|}
\hline $\begin{array}{l}\text { Game } \\
\text { Developer }\end{array}$ & Factor & That Impede From Game Developers' Perspective \\
\hline \multirow{4}{*}{ Touchten } & a) & $\begin{array}{l}\text { Does not believe in Indonesian Law because its enforcement is not } \\
\text { well-implemented in Indonesia. }\end{array}$ \\
\hline & b) & $\begin{array}{l}\text { Does not understand about the provisions in Copyright Law that exist } \\
\text { in Indonesia and does not even know that there is Directorate General } \\
\text { of IP exists to help everything in regards to Copyright }\end{array}$ \\
\hline & c) & $\begin{array}{l}\text { Lack of information in regards to the legal protection of copyright of } \\
\text { video game in Indonesia }\end{array}$ \\
\hline & d) & $\begin{array}{l}\text { Has not focused on legal aspect, tends to think that it is better to } \\
\text { spend the time and money for the development of the game rather } \\
\text { than for the legal protection }\end{array}$ \\
\hline
\end{tabular}




\begin{tabular}{|c|c|c|}
\hline \multirow{4}{*}{$\begin{array}{l}\text { Toge } \\
\text { Productions }\end{array}$} & a) & $\begin{array}{l}\text { Personally thinks that the copyright law in Indonesia is not strong. } \\
\text { Underestimates the legislator and law enforcer because they believe } \\
\text { that the the law makers do not understand about video game }\end{array}$ \\
\hline & b) & $\begin{array}{l}\text { Lack of information in regards to the legal protection of copyright of } \\
\text { video game in Indonesia }\end{array}$ \\
\hline & c) & $\begin{array}{l}\text { Does not care if the video game they created got pirated. Proud } \\
\text { when the video game got pirated and think that piracy as medium for } \\
\text { promotion of the video game }\end{array}$ \\
\hline & d) & $\begin{array}{l}\text { Has not focused on legal aspect, more focus on the development of } \\
\text { the game, if there is infringement then they will start to find the legal } \\
\text { remedy that they can do }\end{array}$ \\
\hline \multirow{4}{*}{$\begin{array}{l}\text { Maulidan } \\
\text { Games }\end{array}$} & a) & Does not understand about Copyright Law that exist in Indonesia. \\
\hline & & $\begin{array}{l}\text { Knows that there is copyright law but does not know that the } \\
\text { protection is obtained automatically, thinks that the protection }\end{array}$ \\
\hline & & obtained from the registration of the ceation \\
\hline & b) & $\begin{array}{l}\text { Lack of information in regards to the legal protection of copyright of } \\
\text { video game in Indonesia }\end{array}$ \\
\hline \multirow{5}{*}{ Mojiken } & a) & $\begin{array}{l}\text { Does not understand about Copyright Law that exist in Indonesia. } \\
\text { Does not know that video game is one of the creation protected under } \\
\text { Copyright Law }\end{array}$ \\
\hline & b) & $\begin{array}{l}\text { Knows that there is copyright law but does not know that the } \\
\text { protection is obtained automatically, they think that the protection } \\
\text { obtained from the registration of the ceation }\end{array}$ \\
\hline & c) & $\begin{array}{l}\text { Proud when the video game got pirated and think that piracy as } \\
\text { medium for promotion of the video game }\end{array}$ \\
\hline & d) & $\begin{array}{l}\text { Lack of information in regards to the legal protection of copyright of } \\
\text { video game in Indonesia }\end{array}$ \\
\hline & e) & $\begin{array}{l}\text { Mojiken is small developer then there is no need to focus on the legal } \\
\text { aspect because they do not have much resources }\end{array}$ \\
\hline
\end{tabular}

\section{Conclusion}

Based on the research that has been conducted by the Author in regards to the protection of video game in Indonesia and based on the discussion on the previous chapters, it can be concluded that the infringements which are often encountered regarding copyright protection of video games in Indonesia are; moral rights infringement to change the title of the creator's creation without permission, economic rights infringement by publishment, duplication, annoucement and distribution of creation without permission creator. Such infringements are the infringements of Article 5 paragraph 1 (a) and economic rights of the creator in 
Article 9 paragraph 1 Letter a, Letter b, Letter e, and Letter g. Furthermore, piracies become the most often cases, the game developers call it as Illegal Porting. Video game piracy often occurs because for the person who understands, hijacking a particular game is very easy to do especially if lack of protection by the creator.

The legal protection of copyright for video game developers in Indonesia conducted by game developer are commonly done by using a technology approach called Digital Right Management System (DRM) by the method of cryptography (encryption and decryption), Steganography, Digital Watermarking and Obfuscation. For the efforts to settle the dispute which already occurred are by conducting consultation to get legal advise and give warning letter to the party that infringed their copyright. In fact, there is no video game developer who has registered the copyright of video games made by them for various reasons such as these activities to spend a lot of time, effort, and money. Litigation measure to settle the dispute of copyright infringement also has never been conducted because the judiciary are considered to have too heavy burden, waste of time, very expensive, and it is considered too formalistic and too technically.

Factors that impede the legal protection of video game in Indonesia are; Game developers are less convinced by the existing law due to lack of knowledge of the developers of the copyright law in Indonesia, legal factors starting from the lack of clarity on the scope and limits of copyright infringement of video games, and the investigators who do not understand the technical aspects of video game making it difficult for them in the process of inquiry and investigation. Further, the development of Internet technology allows for the dissemination of information widely, making it easier to reproduce, modify, copyrighted works video game illegally. Lastly, a factor from society who do not have legal awareness on the importance of copyright because majority of Indonesian people lack knowledge of the law and understanding of the law.

After connecting the legal theory with the field practice by interviewing the game developers, the author would like to recommend several things. The government, in this case the department of Transportation, Communication and 
Information, Ministry of Justice, Police, Ministry of Tourism and Creative Economy must play an active role to disseminate the information about the enforcement of copyright law to the entire community, as well as game developers and dissemination on the importance of copyright registration in order to get legal protection of video games' copyright.

The government, in this case the department of Transportation, Communication and Information, Ministry of Justice, Police, Ministry of Tourism and Creative Economy must play an active role to promote comprehension and understanding of the consequences of the violation of the Copyright and give more severe sanctions to the people who infringe the copyright of another.

The government is advised to add expertise in the technology for investigation process against video game's copyright infringement, especially relating to the internet connection. There needs to be clear and firm regulations on the scope of copyright protection of video games and clear limits of similarity to the work of video games. There should be guidance from the legislative to the law enforcement officials regarding the scope of the infringement, to make it less confusing.

A special sort of body or organization is needed as a communicator among game developers with the government to make common perception between game developer and lawmakers in the making of specific regulations on video games. The proactive role of game developers in both preventive legal protection and repressive to be aware and further immediately report if there is criminal offenses in the field of video games, in order ensure active cooperation between the government and the public.

Game developers are suggested to have a special division that handles legal issues so that when there is a dispute about video games or anything related to legal matters, the division can directly handle these problems. In addition, the division also can be used as prevention or protection for game developers.

As evidence in the event of copyright disputes of video games, game developers are suggested to register the copyright of video game they made to the Directorate General of Copyright. Copyright registration of video game is expected to provide some sort of legal certainty and further facilitate the transfer of rights of the creation. 


\section{Bibliography}

\section{Books}

Aprinus Salam, Negara Dan Perubahan Sosial, Sastra (Pusat Studi Kebudayaan UGM 2010).

David Greenspan, Video Game and IP: Global Perpective (WIPO Magazine 2014).

Greville, Davidson and S, Legal Research and Writing in New Zealand (3rd edn, Lexis Nexis 2007).

James Butch Rosser, Playin'To Win: A Surgeon, Scientist and Parent Examines the Upside of Video Games (Morgan James Publishing 2009).

Kompas, 'Indonesia Abad XXI, Di Tengah Perubahan Global' Kompas (Jakarta, 2000).

Michele D. Scott, Scott of Multimedia Law 3rd Edition Vol. 1 (Wolter Kluwers Law and Business 2008).

Nicholas Walliman, Your Undergraduate Dissertation (Sage Publication 2004).

Pepen Supende and Nurhidayat, Fun Game 50 Permainan Menyenangkan Indoor Dan Outdoor (Penebar Swadaya 2008).

Peter Mahmud Marzuki, Penelitian Hukum (Kencana Prenadamedia Group 2005).

Rudi Susilana dan Cepi Riyana, Media Pembelajaran: Hakikat, Pengembangan, Pemanfaatan, Penilaian (CV Wacana Prima 2009).

Rusel DeMaria, Reset: Changing the Way We Look at Video Games (PTY Ltd 2008).

Samaun Samadikun, Sang Petani Silikon Indonesia (LIPI Press 2007).

Samuel Henri, Cerdas Dengan Game (Gramedia Pustaka Utama 2010).

Soerjono Soekanto, Pengantar Penelitian Hukum (UI-Press 1984).

—_, Penelitian Hukum Normatif (Raja Grafindo Persada 2006).

SuharsiniArikunto,ProsedurPenelitian:SuatuPendekatanPraktek(RinekaCipta1996).

\section{Internet}

Badan Pengkajian dan Penerapan Teknologi Hak Kekayaan Inteletual, 'Pengakuan 
Hak Kekayaan Intelektual Di Indonesia' (Badan Pengkajian dan Penerapan Teknologi Hak Kekayaan Inteletual, 2011) <http://hki.bppt.go.id/index. php?option=com_content\&view=article\&id=15\&Itemid=19> accessed 13 April 2019.

Luke Graham, 'Can Video Game Piracy Be Stoped in Two Years?' (CNBNC. com, 2019) <http://www.cnbc.com/2016/01/14/can-video-game-piracy-bestopped-in-two-years.html $>$ accessed 14 April 2019.

Science for All Americans Online, 'Chapter 3: Nature of Technology, Issues in Technology' (Science for All Americans Online, 2019) <http://www. project2061.org/publications/sfaa/online/chap3.htm\#top.> accessed 12 April 2019.

The University of Texas Medical Branch (UTMB), 'UTMB's Dr. Kilic on the Robotic Simulator Training Study' (The University of Texas Medical Branch (UTMB), 2019) <https://www.youtube.com/watch?v=9hhnG-uwq4o> accessed 9 April 2019.

HOW TO CITE: Juanda Maria Angelia Yolesa, Annisa Ayu Mulia and Camellia Anand, 'Copyright Protection of Video Game for Game Developer in Indonesia' (2019) Vol. 2 No. 2 Notaire. 
--This page is intentionally left blank-- 